\title{
Percutaneous Endoscopic Tube
}

National Cancer Institute

\section{Source}

National Cancer Institute. Percutaneous Endoscopic Tube. NCI Thesaurus. Code C93308.

A hollow tube that is inserted into to the stomach through a surgical incision in the abdominal wall. 